\title{
Extrahepatic Manifestations and Autoantibodies in Patients with Hepatitis C Virus Infection
}

\author{
Takashi Himoto $^{1,2}$ and Tsutomu Masaki ${ }^{1}$ \\ ${ }^{1}$ Department of Gastroenterology and Neurology, Kagawa University School of Medicine, Kagawa, Japan \\ ${ }^{2}$ Department of Integrated Medicine, Kagawa University School of Medicine, 1750-1, Ikenobe, Miki-Cho, \\ Kita-Gun, Kagawa 761-0793, Japan
}

Correspondence should be addressed to Takashi Himoto, thimoto@med.kagawa-u.ac.jp

Received 27 April 2012; Revised 13 June 2012; Accepted 13 June 2012

Academic Editor: Domenico Sansonno

Copyright (C) 2012 T. Himoto and T. Masaki. This is an open access article distributed under the Creative Commons Attribution License, which permits unrestricted use, distribution, and reproduction in any medium, provided the original work is properly cited.

Patients with chronic hepatitis $\mathrm{C}$ virus $(\mathrm{HCV})$ infection frequently have many extrahepatic manifestations, as persistent $\mathrm{HCV}$ infection often triggers lymphoproliferative disorders and metabolic abnormalities. These manifestations primarily include autoimmune disorders such as cryoglobulinemia, Sjögren's syndrome, and autoimmune thyroid disorders. It has been well established that chronic HCV infection plays important roles in the production of non-organ-specific autoantibodies, including antinuclear antibodies and smooth muscle antibodies, and organ-specific autoantibodies such as thyroid autoantibodies. However, the clinical significance of autoantibodies associated with the extrahepatic manifestations caused by HCV infection has not been fully recognized. In this paper, we mainly focus on the relationship between extrahepatic manifestations and the emergence of autoantibodies in patients with HCV infection and discuss the clinical relevance of the autoantibodies in the extrahepatic disorders.

\section{Introduction}

Persistent hepatitis C virus (HCV) infection has been well characterized as having a preferential evolution which often evokes lymphoproliferative disorders [1] and metabolic abnormalities [2]. Therefore, patients with chronic HCV infection frequently develop extrahepatic manifestations [35]. Previous studies have revealed that $38-76 \%$ of patients with chronic HCV infection develop at least one extrahepatic manifestation [6-8]. These extrahepatic manifestations mainly include autoimmune disorders such as mixed cryoglobulinemia, Sjögren's syndrome, and thyroid autoimmune disorders.

On the other hand, persistent HCV infection is responsible for the production of a variety of autoantibodies including non-organ-specific autoantibodies and organ-specific autoantibodies, as a virus-induced autoimmune phenomenon. The diversity of autoantibodies in the sera of patients with HCV-related chronic liver disease (CLD) [9-13] has been shown. Some autoantibodies in chronic HCV infection have biochemical, histological, or genetic characteristics, while other autoantibodies may predict the response to antiviral treatments, concomitant disorders, or prognosis in patients with HCV-related CLD [14].

Various mechanisms for the production of autoantibodies in patients with HCV-related CLD have been proposed. Molecular mimicry between a component of a virus and a "self" protein may account for the production of autoantibodies in chronic HCV infection [15]. A sequence homology between the HCV polyprotein and cytochrome p450 2D6 (CYP 2D6), which was identified as the antigenic target of antibodies to liver-kidney microsome type 1 (anti-LKM1), was previously reported [16]. The reactivity against the viral protein induces the production of anti-LKM1 in HCVrelated CLD. Polyclonal B-cell activation by persistent HCV infection has been proposed as another mechanism for the production of autoantibodies [17]. B-cell proliferation seems to be essential for the development of autoimmune disorders including Sjögren's syndrome and mixed cryoglobulinemia (MC). Genetic predisposition is also strongly related to 
the presence of autoantibodies in chronic HCV infection [18]. The susceptibility to develop non-organ specific autoantibodies (NOSA) appears to be restricted to a specific human leukocyte antigen (HLA) in patients with HCV infection [19].

The presence of NOSA including antinuclear antibodies (ANAs) and smooth muscle antibodies (SMAs) is associated with the severity of necroinflammation and fibrosis in the liver of patients with HCV-related CLD [20-24]. It is notable that the titers of these autoantibodies seem to be independent of HCV genotypes or loads of HCV-RNA [21-25]. The emergence of these autoantibodies did not affect antiviral treatments. [23]. However, we have to exclude concomitant autoimmune hepatitis (AIH) from patients with HCV infection seropositive for NOSA, because antiviral treatment occasionally exacerbates AIH in those patients [26].

The clinical significance of autoantibodies in the extrahepatic manifestations caused by HCV infection has been rarely discussed. This paper highlights the aspects of autoantibodies in extrahepatic manifestations by HCV infection and elucidates their clinical and therapeutic implications.

\section{Extrahepatic Manifestations and Their Associated Autoantibodies}

2.1. Cryoglobulinemia. Cryoglobulinemia is one of the most common extrahepatic diseases in patients with HCV infection and is detected in $19-54 \%$ of those patients [8, 27-30]. Cryoglobulins are immunochemically classified into three types according to the method by Brouet and his colleagues [31]. Type I cryoglobulins are composed of a monoclonal immunoglobulin and are often associated with hematological disease. Type II cryoglobulins are immune complexes consisting of polyclonal IgG with monoclonal rheumatoid factor (RF) activity, while type III cryoglobulins are characterized by polyclonal IgG with polyclonal RF. Therefore, type II and type III cryoglobulins are referred to mixed cryoglobulins. Persistent HCV infection is strongly associated with types II and III mixed cryoglobulinemia (MC) and occasionally associated with type I cryoglobulinemia. Cryoprecipitates contain $\mathrm{HCV}$ core proteins, IgG molecules with specific anticore activities, and IgM molecules with $\mathrm{RF}$ activities. C1q proteins and $\mathrm{Clq}$ binding activity were enriched in this immune complex [32], and were related to the wide expression of $\mathrm{Clq}$ receptor on the surface of blood cells and endothelial cells [33-35].

MC secondary to HCV infection often involves other organ systems in, for example, cutaneous manifestations, peripheral neuropathy, and glomerular disease $[1,36,37]$. There are interesting issues in the relationship between the emergence of cryoglobulin and more advanced hepatic fibrosis in patients with chronic HCV infection [27, 30, 38, 39]. However, all patients with HCV-related MC do not suffer from these involvements $[8,25,30]$. Overt vasculitis is observed in only $2-3 \%$ of patients with HCV-related MC $[7,40,41]$. The circumstances predisposing HCV-infected patients to develop these manifestations remain obscure.
It is noteworthy that cryoglobulins are usually found at low concentrations in patients with chronic HCV infection $[25,28,29]$. Patients with HCV-related cryoglogulinemic vasculitis had higher cryocrit levels than those without vasculitis [42]. Patients with cryoglobulinemic vasculitis had clinical characteristics of female-predominance, older age and longer disease duration [42]. The natural history and prognosis of cryoglobulinemic vasculitis was highly dependent on renal involvement or the severity of vasculitis lesion.

The precise mechanism by which HCV infection involves MC has not been well established. However, one hypothesis of a possible role played by HCV in polyclonal B-cell response has been proposed as follows: HCV has a strong affinity to the tetraspanin (CD81) ligand on the surface of B lymphocytes via the E2 protein (the second proportion of the HCV envelope) [43]. CD81 forms a costimulatory complex with CD19 and CD21 [44]. The ligation of CD81 on B cells results in the activation of this complex, which lowers the antigen threshold necessary for antibody production and eventually causes the formation of cryoglobulins [33]. The cryoglobulins initially produced are polyclonal IgG (type III $\mathrm{MC}$ ), but as a dominat B-cell clone emerges, it may produce monoclonal immunoglobulins (type II MC) [9].

On the other hand, B-cell-activating factor (BAFF), a member of the tumor necrosis factor-alpha (TNF- $\alpha$ ) family that plays crucial roles in B-cell differentiation, survival, and immunoglobulin secretion, is considered to be associated with the development of autoimmune disorders [45]. The elevation of serum BAFF levels was observed in patients with HCV-related lymphoproliferative disorders [46, 47] which represents a link between infection and autoimmunity. Quantitative decrease in regulatory $\mathrm{T}$ cells may be involved in patients with HCV-related MC [48].

Serological hallmarks reflecting autoimmunity in patients with HCV-related MC have been fully recognized. Table 1 summarizes the clinical characteristics of autoantibodies in patients with HCV-related MC. Non-organspecific autoantibodies including ANA and SMA have been observed in $12-65 \%[8,29,36,49-52]$ and $33-37 \%[8,53]$ of patients with HCV-related MC, respectively. It is noteworthy that the immunofluorescence pattern of ANA on HEp-2 cells in HCV-related MC was speckled [47, 51]. Rheumatoid factor (RF), which recognizes the Fc portion of IgG molecules as their antigens, often appears in sera of patients with HCV-related MC, at frequencies of 14 to $99 \%$ of those patients $[30,36,49,52,54,55]$. However, the titers of ANA and RF in sera of HCV-related MC were less than 1:80 and $50 \mathrm{UI} / \mathrm{mL}$, respectively [51], which appeared to be low. Antineutrophil cytoplasmic antibodies (ANCAs), which are divided into two groups by immunofluorescence patterns: pANCA and cANCA [56], are also present in the sera of patients with HCV-related MC $[8,57,58]$. However, the occurrence of these autoantibodies was not necessarily related to HCV-related cryoglobulinemic vasculitis [57].

Some types of autoantibodies are available for predictive markers of HCV-related MC. The presence of circulating autoantibodies to C-reactive protein antibodies (anti-CRP), which are directed against monomeric CRP [64], was dependent on HCV-related MC $[59,60]$. In addition, antibodies 
TABLe 1: Autoantibodies detected in sera of patients with HCV-related MC.

\begin{tabular}{lclc}
\hline Autoantibodies & Frequency $(\%)$ & Clinical significance & References \\
\hline ANA & $12-65 \%$ & Low titer & {$[8,30,37,49-52]$} \\
SMA & $33-37 \%$ & Speckled pattern on HEp-2 cells & {$[8,53]$} \\
RF & $14-99 \%$ & Low titer & {$[30,37,49,52,54,55]$} \\
ANCA (pANCA, cANCA) & $4-26 \%$ & No association with vasculitis & {$[57,58]$} \\
Anti-CRP & $75 \%$ & Predictive marker of cryoglobulinemia & {$[59,60]$} \\
Anti-C1q & $39 \%$ & Predictive marker of type III cryoglobulinemia & {$[61]$} \\
AECA & $50 \%$ & Predictive marker of vasculitis & {$[62]$} \\
Anti-GM1 ganglioside antisulfatide & $52 \%$ & Predictive marker of peripheral neuropathy & {$[63]$} \\
\hline
\end{tabular}

to $\mathrm{Clq}$, which is closely associated with immune complex diseases including hypocomplementaemic urticarial vasculitis and systemic lupus erythematosus (SLE) [65], was detected in $38 \%$ of patients with chronic HCV infection [66], implying that the emergence of anti-C1q represented concurrent cryoglobulinemic vasculitis. However, Saadoun and his colleagues revealed that anti-C1q was not associated with cryoglobulinemic vasculitis, but indicated the susceptibility to type III MC in those patients [61].

Other types of autoantibodies are closely linked to the organ involvements in patients with HCV-related MC. Positivity for RF seems to reflect the development of cutaneous vasculitis in patients with HCV-related MC. Karisberg and his colleagues demonstrated that all HCV-related MC patients with cutaneous vasculitis had RF and liver involvement [67]. The detection of Type II cryoglobulins containing RF (type II-RF) appeared to monitor cryoglobulinemic vasculitis in those patients [68]. IgM $\kappa$ RF was strongly associated with membranoproliferative glomerulonephritis (MPGN) in type II MC [69]. On the other hand, a recent study reported by Knight and his colleagues elucidated that the monoclocal RFs that bear the WA cross-idiotype are responsible for vasculitis in patients with HCV-related MC [70].

Antiendothelial cell autoantibodies (AECAs) were recently identified as a serum parameter for an autoantibody against a variety of antigen determinations on endothelial cells and their titers represented the activity of vasculitis [71]. Cacoub and his colleague revealed that AECA was present in $50 \%$ of patients with HCV-related MC and that seropositivity for AECA was associated with the prevalence of vasculitis and serum cryoglobulin levels in those patients [62]. However, the authors did not describe the correlation between the AECA titers and the activity of vasculitis. Elevated soluble vascular cell adhesion molecule-1 (VCAM-1) was likely to contribute to the involvement of vasculitis in HCV-related MC. Therefore, AECA-induced activation of endothelial cells may initiate an upregulation in the expression of endothelial adhesion molecule.

The analysis of antineuroual antibodies [72] including anti-ganglioside GM1 and anti-sulfatide antibodies was performed using the sera of HCV-related MC [63]. The association between those titers and the involvement of the peripheral nervous system was apparent in patients with HCV-related MC.
Genetic susceptibilities may be related to the development of MC in patients with chronic HCV infection. HLA DRB1*11 (DR11) was found to predict cryoglobulinemic vasculitis in patients with HCV infection, whereas HLA DR7 seemed to protect from the development of type II MC $[73,74]$.

2.2. Sjögren's Syndrome. Sjögren's syndrome (SS) is another common extrahepatic manifestation caused by HCV infection. $6-26 \%$ of patients with chronic HCV infection complain of sicca syndrome (xerostomia and/or xerophthalmia) $[6-8,33,75,76]$. The pathogenesis of HCV-associated SS is not well established. The virus is unlikely to have a direct effect, because HCV has not been proven in glandular tissue $[77,78]$. The proposed mechanism includes cross-reactivity between the HCV envelope and host salivary tissue or $\mathrm{HCV}$ envelope-mediated salivary glands. Koike and his colleagues elucidated the resemblance of salivary lesions from a transgenic model overexpressing the $\mathrm{HCV}$ envelope protein [79].

SS secondary to HCV infection can be distinguished, to some extent, from primary SS by analyzing several types of autoantibodies (Table 2). The seropositivities for antibodies to SS-A/Ro and to SS-B/La are much lower in HCV-associated SS than those in primary SS patients $[75,80]$. The prevalences of cryoglobulin and RF were higher in the sera of patients with HCV-associated SS than in those of primary SS patients $[75,80,81]$. It is of interest that the coexistence of cryoglobulinemia in HCV-related SS may favor the development of lymphoproliferative diseases including B-cell NHL [82]. There has been recent discussions on the relevance of antibodies to alpha-fodrin in patients with $\mathrm{HCV}$ related SS seronegative for antibodies to SS-A/Ro [83].

Apart from the antibody status, HCV-related SS has several clinical characteristics distinct from primary SS. Biochemical analysis revealed a higher frequency of hypocomplementemia in HCV-SS than primary SS $[80,84]$. The imbalance of Th1/Th2, namely, poor Th1 response and enhanced Th2 response, was apparent in HCV-related SS [80]. A recent study revealed that the detection of monoclonal gammopathy $(\operatorname{IgM} \kappa)$ might help to distinguish HCVrelated SS from primary SS [85]. De Vita and his colleagues documented higher prevalence of monoclonal gammopathy 
TABLE 2: Comparisons of immunological and histological findings between primary SS and HCV-related SS.

\begin{tabular}{lll}
\hline Variable & Primary SS & HCV-related SS \\
\hline Autoantibodies & High frequency of ANA, anti-Ro, and anti-La & Low frequency of ANA, anti-Ro, and anti-La \\
Cryoglobulin & Rare & Common \\
Hypocomplementemia & Rare & Common \\
Lymphocytic capillaritis & Moderate to severe & Mild to moderate \\
Th1/Th2 balance & Th1 predominant & Th2 predominant \\
Monoclonal gammopathy & Low & High \\
Association of HLA DR-3 & High & Low \\
\hline
\end{tabular}

in HCV-related SS than that in primary SS [86]. Histological examination of the salivary gland in HCV-related SS showed milder pericapillary and nonpericanalary lymphocytic infiltration than primary SS [87]. The prevalence of liver involvement was far higher in HCV-related SS than in primary SS [84].

Patients with the HLA haplotype of HLA DQB1* 02 had a susceptibility to the development of HCV-related SS [88]. On the other hand, the prevalence of HLA DR 3 [89], a haplotype specific to primary SS, was far lower in patients with HCVrelated SS [75].

2.3. Autoimmune Thyroid Disease. Thyroid disorders are common in patients with chronic HCV infection. Approximately $10-25 \%$ of patients with persistent HCV infection have thyroid autoantibodies, including thyroid microsome autoantibodies (TMAs), thyroglobulin autoantibodies (TGAs), and antibodies to thyroid peroxidase autoantibodies (anti-TPO), regardless of the liver involvement severity [9092]. TMAs are frequently useful to detect latent autoimmune thyroiditis in patients with $\mathrm{CH}-\mathrm{C}$ prior to antiviral treatment [91]. The presence of TMAs also may predict thyroid dysfunction including hyperthyroidism and hypothyroidism [93]. Therefore, the detection of these thyroid autoantibodies is considered useful for the clinical diagnosis of concurrent autoimmune thyroid diseases in patients with HCV infection. However, HCV-associated thyroid disorders cannot be distinguished from primary thyroid disorder by the existence of these thyroid autoantibodies. The possible role of $\mathrm{HCV}$ in the development of thyroid disorders has not been fully understood.

HCV-related thyroid disorders include Graves' disease and Hashimoto's thyroiditis induced by interferon (IFN) treatment $[94,95]$. The discovery of anti-TPO at base-line may be regarded as a predictive factor for IFN-induced thyroid autoimmunity in patients with $\mathrm{CH}-\mathrm{C}$. A strong correlation between thyroid disorders and the presence of anti-LKM1 at base-line in patients with chronic hepatitis C was also observed [96, 97]. HCV poly protein, CYP2D6 and thyroperoxidase are likely to share epitopes encoding homologous amino acid sequences [97]. Therefore, seropositivity for anti-LKM1 is a susceptibity factor for IFN-induced autoimmune thyroid disorders in patients with HCV-related CLD.
2.4. Lichen Planus. Lichen planus is well known to be a skin lesion associated with persistent HCV infection, although the pathogenesis remains uncertain [98]. Approximately $1-6 \%$ of patients with chronic HCV infection have been estimated to be afflicted with oral lichen planus [7, 8, 49]. The existence of concurrent lichen planus was associated with chronic active hepatitis [99], suggesting that the chronic $\mathrm{HCV}$ infection alone did not cause lichen planus. However, the severity of hepatic fibrosis and necroinflammation was independent of the severity of lymphocytic infiltration in the oral lichen planus [100].

Nagao and her colleagues revealed that the emergence of antibodies to cardiolipin (anti-CL), the hallmark of antiphospholipid syndrome [101], might reflect concurrent oral lichen planus in patients with chronic HCV infection [102], although the association seems to be controversial [103]. Surprisingly, these patients with anti-CL did not fulfill the criteria for antiphospholipid syndrome [102]. The emergence of TMA may be associated with oral lichen planus secondary to HCV infection [104], although the putative mechanism was not described in detail. Clinical relevance of antibodies to epithelial components in HCV-associated oral lichen planus was also reported [105]. To the contrary, Carrozzo and his colleagues elucidated no relationship between the emergence of autoantibodies including ANA, SMA, parietal cell antibodies, and anti-epithelial antibodies and concomitant lichen planus in patients with HCV infection [106]. Another study revealed that cryoglobulin-positive patients with $\mathrm{CH}-\mathrm{C}$ had higher prevalence of lichen planus than cryoglobulin-negative patients [6].

2.5. CREST Syndrome. CREST syndrome is a rare concurrent autoimmune disease in patients with persistent $\mathrm{HCV}$ infection [3]. We previously elucidated that approximately $1 \%$ of patients with HCV-related CLD have anticentromere antibodies (ACAs) [107], the serological hallmark of CREST syndrome [108]. However, all patients seropositive for ACA did not have symptoms of CREST syndrome [107], like the cases of primary biliary cirrhosis (PBC) patients with ACA [109]. The putative role of persistent HCV infection in the production of ACA remains uncertain, although the molecular mimicry between the HCV core antigen and CENP-A [110], one of the major centromere proteins [111], has been shown. 
2.6. IFN-Induced Autoimmunity. Treatment with IFN- $\alpha$, an antiviral drug, can precipitate or exacerbate autoimmune endocrine diseases as well as autoimmune thyroid disorders in patients with $\mathrm{CH}-\mathrm{C}$ [101]. Treatment with IFN- $\alpha$ resulted in the upregulation of major histocompatibility complex (MHC) class I expression on thyroid epithelial cells and switching the immune response to the Th1 pattern and subsequent cytokine release (IFN- $\gamma$ and interleukin-2) [93$95,112]$. The thyroid was the organ most susceptible to treatment with IFN- $\alpha$ in patients with CH-C [113].

The association of the IFN treatment with the development of type 1 diabetes mellitus (DM) has been shown in patients with $\mathrm{CH}-\mathrm{C}$ patients. Of all $\mathrm{CH}-\mathrm{C}$ patients, $1.4-2.8 \%$ had antibodies to glutamic acid decarboxylase (anti-GAD), the serological hallmark of type $1 \mathrm{DM}$ [114], prior to the treatment with IFN- $\alpha[115,116]$. Most $\mathrm{CH}-\mathrm{C}$ patients with anti-GAD developed type $1 \mathrm{DM}$ by the IFN therapy. The onset of type $1 \mathrm{DM}$ was closely restricted to the genetic susceptibility demonstrated by the presence of the HLA DRB1DQB1 haplotype in those patients [117].

Antibodies to 21 -hydroxylase were observed in $4.8 \%$ of patients with $\mathrm{CH}-\mathrm{C}$ receiving IFN treatment. However, the presence of this autoantibody was independent of adrenal failure [118].

The existence of non-organ-specific autoantibodies including ANA at end of the treatment or the increase in titers of SMA can predict unfavorable outcomes of antiviral treatments in patients with $\mathrm{CH}-\mathrm{C}$ [119].

It is of interest that Covini and his colleagues identified a novel autoantigen, which appeared like distinct rods and rings (RRs) in the cytoplasm of HEp-2 cells, in patients with $\mathrm{CH}-\mathrm{C}$ under treatment with pegylated IFN- $\alpha$ and ribavirin [120].

Genetic backgrounds may trigger the development of IFN-induced thyroid disorders. There was a close correlation between HLA A2 and IFN-induced autoimmune thyroiditis in Japanese patients with $\mathrm{CH}-\mathrm{C}$ [121]. Another study revealed the association of DRB1* 11 with IFN-induced autoimmune thyroiditis in a Caucasian population [122].

2.7. Malignant Transformation. An oncogenic role in chronic HCV infection has been widely shown by the development of hepatocellular carcinoma (HCC) and B-cell NHL [123]. The close relationship between carcinogenesis and autoimmunity has been also well recognized.

A previous issue revealed that the minority of patients with HCV-related MC (5-10\%) develop a frank malignant lymphoma in long-term follow-up [124]. The clonal B-cell expansion by HCV infection may account for the malignant transformation in patients with HCV-related MC [125]. The $t(14: 18)$ translocation with overexpression of bcl-2 antiapoptotic protein [126] in B cells leading to extension of B-cell survival $[127,128]$ and the subsequent mutations of oncogenes including c-myc and p53 $[129,130]$ seemed to play essential roles in the development of B-cell NHL.

A strong linkage between HCV-related SS and B-cell NHL has been widely documented. Ramos-Casals and his colleagues recently demonstrated that patients with HCVrelated SS who developed NHL had the immunological features of higher prevalence of RF and type II MC than those with HCV-related SS without NHL [82].

Monoclonal gammopathy of undetermined significance (MGUS) has been recognized as another lymphoproliferative disorder in HCV-related MC [131]. The monoclonal gammopathies of $\operatorname{IgG} \kappa$ and $\operatorname{IgM} \kappa$ are frequently observed in HCV-related MC [132]. The monoclonal gammopathy in those patients should be monitored to exclude the possibility of an evolution to multiple myeloma [133].

Raedle and his colleagues revealed that three of 7 (43\%) patients with HCV-related HCC had autoantibodies to p53 [134], one of the tumor-associated antigens [135], while none of the patients with HCV-related CLD did, suggesting that $\mathrm{HCV}$-induced carcinogenesis resulted in the production of these autoantibodies. On the other hand, the prevalence of autoantibodies to survivin [136], a protein which belongs to the inhibitor-of-apoptosis protein (IAP) family [137], was higher in patients with HCV-related HCC than in those with HBV-related HCC. We previously reported 8 of 86 (9\%) patients with HCC had autoantibodies to tumor-associated antigens including p53, insulin-like growth factor II $m$ RNAbinding proteins (IMPs), c-myc, and survivin $[138,139]$. It is of note that seven of 8 HCC patients with those antibodies were $\mathrm{HCV}$ related $[138,139]$.

A few types of autoantibodies frequently observed in autoimmune diseases are generally present in sera of patients with HCC. There is an interesting issue on the relationship between autoantibodies to Golgi, which are usually seen in the patients with rheumatoid arthritis and SLE [140] and HCV-related HCC [141]. Our present report revealed that patients with HCV-related CLD seropositive for ACA frequently developed HCC [107]. Antibodies to CENP-B, the most common target antigen of ACA, were regarded as a potential biomarker for small-cell lung cancer [142].

2.8. Autoimmune Cytopenia. As another extrahepatic manifestation, reports of HCV-related autoimmune cytopenia including autoimmune hemolytic anemia (AHA), autoimmune thrombocytopenia, and autoimmune neutropenia are recently increasing in number [143]. It is of interest that patients with HCV-related AHA are often associated with the emergence of ANA and MC [143]. Patients with HCVrelated autoimmune thrombocytopenic purpura also had more immunological markers [144].

On the other hand, $66-88 \%$ of patients with chronic HCV infection and thrombocytopenia had antiplatelet antibodies $[145,146]$, although the development of antiplatelets is not associated with thrombocytopenia. The most common target antigen of anti-platelet antibodies is glycoprotein (GP) IIb/IIIa [146].

2.9. Atherosclerosis. Atherosclerosis has been described as a metabolic abnormality caused by HCV infection [147]. Autoantibodies to oxidized low-density lipoprotein (antiox-LDLs) have been identified as a serological hallmark of 
atherosclerosis [148]. We recently revealed that anti-oxLDLs were associated with the severity of hepatic steatosis in patients with $\mathrm{CH}-\mathrm{C}$ [149]. Further examination will be required whether anti-ox-LDL become a biomarker for atherosclerosis in patients with chronic $\mathrm{HCV}$ infection or not.

\section{Abbreviations}

$\begin{array}{ll}\text { ACA: } & \text { Anticentromere antibodies } \\ \text { AECA: } & \text { Antibodies to endothelial cells } \\ \text { AHA: } & \text { Autoimmune hemolytic anemia } \\ \text { AIH: } & \text { Autoimmune hepatitis } \\ \text { anti-CRP: } & \text { Antibodies to C-reactive protein } \\ \text { anti-GAD: } & \text { Antibodies to glutamic acid decarboxylase } \\ \text { AMA: } & \text { Antimitochondrial antibodies } \\ \text { ANA: } & \text { Antinuclear antibody } \\ \text { anti-CL: } & \text { Antibodies to cardiolipin } \\ \text { anti-IMPs: } & \text { Antibodies to insulin-like growth factor II } \\ & \text { mRNA-binding proteins } \\ \text { anti-LKM1: } & \text { Antibodies to liver kidney microsome type 1 } \\ \text { anti-ox-LDL: } & \text { Antibodies to oxidized low-density } \\ & \text { lipoprotein } \\ \text { anti-TPO: } & \text { Antibodies to thyroid peroxidase } \\ \text { BAFF: } & \text { B-lymphocyte activating factor } \\ \text { c-ANCA: } & \text { Antineutrophil cytoplasmic antibody with } \\ & \text { cytoplasmic pattern, } \\ \text { CH-C: } & \text { Chronic hepatitis C } \\ \text { CLD: } & \text { Chronic liver disease } \\ \text { CYP2D6: } & \text { Cytochrome p450 2D6 } \\ \text { DM: } & \text { Diabetes mellitus } \\ \text { HCC: } & \text { Hepatocellular carcinoma } \\ \text { HLA: } & \text { Human leukocyte antigens } \\ \text { IAP: } & \text { Inhibitor of apoptotic proteins } \\ \text { IFN: } & \text { Interferon } \\ \text { MHC: } & \text { Major histocompatibility complex } \\ \text { NHL: } & \text { Non-Hodgkin's lymphoma } \\ \text { NOSA: } & \text { Non-organ specific autoantibodies } \\ \text { pANCA: } & \text { ANCA with perinuclear pattern } \\ \text { MC: } & \text { Mixed cryoglobulin } \\ \text { PBC: } & \text { Primary biliary cirrhosis } \\ \text { RF: } & \text { Rheumatoid factor } \\ \text { SLE: } & \text { Systemic lupus erythematosus } \\ \text { VCAM-1: } & \text { Vascular cell adhesion molecule-1. } \\ & \text { Thooth muscle antibody } \\ \text { ThAroglobulin antibody } \\ \text { Thyroid microsomal antibody }\end{array}$

\section{References}

[1] A. L. Zignego, C. Giannini, and C. Ferri, "Hepatitis C virusrelated lymphoproliferative disorders: an overview," World Journal of Gastroenterology, vol. 13, no. 17, pp. 2467-2478, 2007.

[2] K. Koike, "Hepatitis C as a metabolic disease: implication for the pathogenesis of NASH," Hepatology Research, vol. 33, no. 2, pp. 145-150, 2005.

[3] J. M. Pawlotsky, M. B. Yahia, C. Andre et al., "Immunological disorders in $\mathrm{C}$ virus chronic active hepatitis: a prospective case-control study," Hepatology, vol. 19, no. 4, pp. 841-848, 1994.

[4] S. J. Hadziyannis, "Nonhepatic manifestations and combined diseases in HCV infection," Digestive Diseases and Sciences, vol. 41, no. 12, pp. 63s-74s, 1996.

[5] V. Agnello and F. G. De Rosa, "Extrahepatic disease manifestations of HCV infection: some current issues," Journal of Hepatology, vol. 40, no. 2, pp. 341-352, 2004.

[6] P. Cacoub, C. Renou, E. Rosenthal et al., "Extrahepatic manifestations associated with hepatitis $\mathrm{C}$ virus infection: a prospective multicenter study of 321 patients," Medicine, vol. 79, no. 1, pp. 47-56, 2000.

[7] P. Cacoub, T. Poynard, P. Ghillani et al., "Extrahepatic manifestations of chronic hepatitis C," Arthritis and Rheumatism, vol. 42, no. 10, pp. 2204-2212, 1999.

[8] D. V. Stefanova-Petrova, A. H. Tzvetanska, E. J. Naumova et al., "Chronic hepatitis $\mathrm{C}$ virus infection: prevalence of extrahepatic manifestations and association with cryoglobulinemia in Bulgarian patients," World Journal of Gastroenterology, vol. 13, no. 48, pp. 6518-6528, 2007.

[9] A. Galossi, R. Guarisso, L. Bellas, and C. Puoti, "Extrahepatic manifestations of chronic HCV infection," Journal of Gastrointestinal and Liver Disease, vol. 16, no. 1, pp. 65-73, 2007.

[10] A. J. Czaja, H. A. Carpenter, P. J. Santrach, S. B. Moore, H. F. Taswell, and H. A. Homburger, "Evidence against hepatitis viruses as important causes of severe autoimmune hepatitis in the United States," Journal of Hepatology, vol. 18, no. 3, pp. 342-352, 1993.

[11] B. D. Clifford, D. Donahue, L. Smith et al., "High prevalence of serological markers of autoimmunity in patients with chronic hepatitis C," Hepatology, vol. 21, no. 3, pp. 613-619, 1995.

[12] P. Muratori, L. Muratori, M. Guidi et al., "Clinical impact of non-organ-specific autoantibodies on response to combined antiviral treatment in patients with hepatitis C," Clinical Infectious Diseases, vol. 40, no. 2, pp. 501-507, 2005.

[13] C. Pallazi, D. Buskila, S. D. Angelo, E. D. Amico, and I. Olivieri, "Autoantibodies in patients with chronic hepatitis $\mathrm{C}$ virus infection: pitfalls for the diagnosis of rheumatic diseases," Aitoimmunity Reviews, vol. 11, no. 9, pp. 659-663, 2012.

[14] T. Himoto and M. Nishioka, "Autoantibodies in hepatitis C virus-related chronic liver disease," Hepatitis Monthly, vol. 8, no. 4, pp. 295-303, 2008.

[15] G. V. Gregorio, K. Choudhuri, Y. Ma et al., "Mimicry between the hepatitis $\mathrm{C}$ virus polyprotein and antigenic targets of nuclear and smooth muscle antibodies in chronic hepatitis $\mathrm{C}$ virus infection," Clinical and Experimental Immunology, vol. 133, no. 3, pp. 404-413, 2003.

[16] D. P. Bogdanos, K. Choudhuri, and D. Vergani, "Molecular mimicry and autoimmune liver disease: virtuous intentions, malign consequences," Liver, vol. 21, no. 4, pp. 225-232, 2001.

[17] F. B. Bianchi, P. Muratori, A. Granito, G. Pappas, S. Ferri, and L. Muratori, "Hepatitis C and autoreactivity," Digestive and Liver Disease, vol. 39, supplement 1, pp. S22-S24, 2007.

[18] S. Ferri, L. Muratori, M. Lenzi, A. Granito, F. B. Bianchi, and D. Vergani, "HCV and autoimmunity," Current Pharmaceutical Design, vol. 14, no. 17, pp. 1678-1685, 2008.

[19] A. J. Czaja, H. A. Carpenter, P. J. Santrach, and S. B. Moore, "Immunologic features and HLA associations in chronic viral hepatitis," Gastroenterology, vol. 108, no. 1, pp. 157-164, 1995. 
[20] F. Cassani, M. Cataleta, P. Valentini et al., "Serum autoantibodies in chronic hepatitis $\mathrm{C}$ : comparison with autoimmune hepatitis and impact on the disease profile," Hepatology, vol. 26, no. 3, pp. 561-566, 1997.

[21] J. C. Luo, S. J. Hwang, C. P. Li et al., "Clinical significance of serum auto-antibodies in Chinese patients with chronic hepatitis C: negative role of serum viral titre and genotype," Journal of Gastroenterology and Hepatology, vol. 13, no. 5, pp. 475-479, 1998.

[22] M. Lenzi, S. Bellentani, G. Saccoccio et al., "Prevalence of non-organ-specific autoantibodies and chronic liver disease in the general population: a nested case-control study of the Dionysos cohort," Gut, vol. 45, no. 3, pp. 435-441, 1999.

[23] M. J. Williams, A. Lawson, K. R. Neal, S. D. Ryder, and W. L. Irving, "Autoantibodies in chronic hepatitis $\mathrm{C}$ virus infection and their association with disease profile," Journal of Viral Hepatitis, vol. 16, no. 5, pp. 325-331, 2009.

[24] P. Chrétien, M. Chousterman, I. A. Alsamad et al., "Nonorgan-specific autoantibodies in chronic hepatitis $\mathrm{C}$ patients: association with histological activity and fibrosis," Journal of Autoimmunity, vol. 32, no. 3-4, pp. 201-205, 2009.

[25] J. M. Pawlotsky, F. Roudot-Thoraval, P. Simmonds et al., "Extrahepatic immunologic manifestations in chronic hepatitis C and hepatitis C virus serotypes," Annals of Internal Medicine, vol. 122, no. 3, pp. 169-173, 1995.

[26] L. Garcia-Buey, C. Garcia-Monzon, S. Rodriguez et al., "Latent autoimmune hepatitis triggered during interferon therapy in patients with chronic hepatitis C," Gastroenterology, vol. 108, no. 6, pp. 1770-1777, 1995.

[27] F. Lunel, L. Musset, P. Cacoub et al., "Cryoglobulinemia in chronic liver diseases: role of hepatitis $\mathrm{C}$ virus and liver damage," Gastroenterology, vol. 106, no. 5, pp. 1291-1300, 1994.

[28] V. S. Wong, W. Egner, T. Elsey, D. Brown, and G. J. M. Alexander, "Incidence, character and clinical relevance of mixed cryoglobulinaemia in patients with chronic hepatitis $\mathrm{C}$ virus infection," Clinical and Experimental Immunology, vol. 104, no. 1, pp. 25-31, 1996.

[29] A. Nagasaki, T. Takahashi, T. Sasaki et al., "Cryoglogulinemia in Japanese patients with chronic hepatitis $\mathrm{C}$ virus infection: host genetic and virological study," Journal of Medical Viro$\log y$, vol. 65, no. 1, pp. 52-57, 2001.

[30] D. Siagris, M. Christofidou, A. Tsamandas, A. Lekkou, K. Thomopoulos, and C. Labropoulou-Karatza, "Cryoglobulinemia and progression of fibrosis in chronic HCV infection: cause or effect?" Journal of Infection, vol. 49, no. 3, pp. 236241, 2004.

[31] J. C. Brouet, J. P. Clauvel, F. Danon, M. Kleim, and M. Seligmann, "Biologic and clinical significance of cryoglobulins. A report of 86 cases," American Journal of Medicine, vol. 57, no. 5, pp. 775-788, 1974.

[32] D. Sansonno, G. Lauletta, N. Nisi et al., "Non-enveloped HCV core protein as constitutive antigen of cold-precititable immune complexes in type II mixed cryoglobulinaemia," Clinical and Experimental Immunology-, vol. 133, pp. 275-282, 2003.

[33] D. Sansonno and F. Dammacco, "Hepatitis C virus, cryoglobulinaemia, and vasculitis: immune complex relations," Lancet Infectious Diseases, vol. 5, no. 4, pp. 227-236, 2005.

[34] M. J. Mayo, "Extrahepatic manifestations of hepatitis C infection," American Journal of the Medical Sciences, vol. 325, no. 3, pp. 135-148, 2003.
[35] D. Sansonno, F. A. Tucci, B. Ghebrehiwet et al., "Role of the receptor for the globular domain of C1q protein in the pathogenesis of hepatitis $C$ virus-related cryoglobulin vascular damage," The Journal of Immunology, vol. 183, no. 9, pp. 6013-6020, 2009.

[36] M. P. Dore, G. Fattovich, A. R. Sepulveda, and G. Realdi, "Cryoglobulinemia related to hepatitis C virus infection," Digestive Diseases and Sciences, vol. 52, no. 4, pp. 897-907, 2007.

[37] D. Saadoun, D. A. Landau, L. H. Calabrese, and P. P. Cacoub, "Hepatitis C-associated mixed cryoglobulinaemia: a crossroad between autoimmunity and lymphoproliferation," Rheumatology, vol. 46, no. 8, pp. 1234-1242, 2007.

[38] W. N. Schmidt, J. T. Stapleton, D. R. LaBrecque et al., "Hepatitis $\mathrm{C}$ virus (HCV) infection and cryoglobulinemia: analysis of whole blood and plasma HCV-RNA concentrations and correlation with liver histology," Hepatology, vol. 31, no. 3, pp. 737-744, 2000.

[39] Z. Kayali, V. E. Buckwold, B. Zimmerman, and W. N. Schmidt, "Hepatitis C, cryoglobulinemia, and cirrhosis: a meta-analysis," Hepatology, vol. 36, no. 4 I, pp. 978-985, 2002.

[40] C. Ferri and M. T. Mascia, "Cryoglobulinemic vasculitis," Current Opinion in Rheumatology, vol. 18, no. 1, pp. 54-63, 2006.

[41] F. Iannuzzella, A. Vaglio, and G. Garini, "Management of hepatitis C virus-related mixed cryoglobulinemia," American Journal of Medicine, vol. 123, no. 5, pp. 400-408, 2010.

[42] D. Sene, P. Ghillani-Dalbin, V. Thibault et al., "Longterm course of mixed cryoglobulinemia in patients infected with hepatitis C virus," Journal of Rheumatology, vol. 31, no. 11, pp. 2199-2206, 2004.

[43] P. Pileri, Y. Uematsu, S. Campagnoli et al., "Binding of hepatitis C virus to CD81," Science, vol. 282, no. 5390, pp. 938941, 1998.

[44] D. T. Fearon and M. C. Carroll, "Regulation of B lymphocyte responses to foreign and self-antigens by the CD19/CD21 complex," Annual Review of Immunology, vol. 18, pp. 393422, 2000.

[45] P. Schneider, F. Mackay, V. Steiner et al., "BAFF, a novel ligand of the tumor necrosis factor family, stimulates B cell growth," Journal of Experimental Medicine, vol. 189, no. 11, pp. 17471756, 1999.

[46] M. Fabris, L. Quartuccio, S. Sacco et al., "B-Lymphocyte stimulator (BLyS) up-regulation in mixed cryoglobulinaemia syndrome and hepatitis-C virus infection," Rheumatology, vol. 46, no. 1, pp. 37-43, 2007.

[47] D. Sène, N. Limal, P. Ghillani-Dalbin, D. Saadoun, J. C. Piette, and P. Cacoub, "Hepatitis C virus-associated B-cell proliferation-the role of serum B lymphocyte stimulator (BLyS/BAFF)," Rheumatology, vol. 46, no. 1, pp. 65-69, 2007.

[48] O. Boyer, D. Saadoun, J. Abriol et al., "CD4 ${ }^{+} \mathrm{CD} 25^{+}$regulatory T-cell deficiency in patients with hepatitis C-mixed cryoglobulinemia vasculitis," Blood, vol. 103, no. 9, pp. 34283430, 2004.

[49] Y. H. Lee, J. D. Ji, J. E. Yeon, K. S. Byun, C. H. Lee, and G. G. Song, "Cryoglobulinaemia and rheumatic manifestations in patients with hepatitis C virus infection," Annals of the Rheumatic Diseases, vol. 57, no. 12, pp. 728-731, 1998.

[50] A. Gad, E. Tanaka, A. Matsumoto et al., "Factors predisposing to the occurrence of cryoglobulinemia in two cohorts of Egyptian and Japanese patients with chronic hepatitis C infection: ethnic and genotypic influence," Journal of Medical Virology, vol. 70, no. 4, pp. 594-599, 2003. 
[51] N. Leone, R. Pellicano, A. Maiocco et al., "Mixed cryoglobulinaemia and chronic hepatitis $\mathrm{C}$ virus infection: the rheumatic manifestations," Journal of Medical Virology, vol. 66, no. 2, pp. 200-203, 2002.

[52] M. Ramos-Casals, L. J. Jara, F. Medina et al., "Systemic autoimmune diseases co-existing with chronic hepatitis $\mathrm{C}$ virus infection (the HISPAMEC Registry): patterns of clinical and immunological expression in 180 cases," Journal of Internal Medicine, vol. 257, no. 6, pp. 549-557, 2005.

[53] F. G. De Rosa, L. P. Pucillo, R. Coviello et al., "Influence of age and autoimmunity on liver disease in $\mathrm{HCV}$-associated type II mixed cryoglobulinemia," Human Immunology, vol. 63, no. 9, pp. 751-757, 2002.

[54] M. Lidar, N. Lipschitz, N. Agmon-Levin et al., "Infectious serologies and autoantibodies in hepatitis $\mathrm{C}$ and autoimmune disease-associated mixed cryoglobulinemia," Clinical Reviews in Allergy and Immunology, vol. 42, no. 2, pp. 238246, 2011.

[55] K. Tanaka, T. Aiyama, J. Imai, Y. Morishita, T. Fukatsu, and S. Kakumu, "Serum cryoglobulin and chronic hepatitis C virus disease among Japanese patients," American Journal of Gastroenterology, vol. 90, no. 10, pp. 1847-1852, 1995.

[56] F. J. van der Woude, M. R. Daha, and L. A. Van Es, "The current status of neutrophil cytoplasmic antibodies," Clinical and Experimental Immunology, vol. 78, no. 2, pp. 143-148, 1989.

[57] P. Lamprecht, O. Gutzeit, E. Csernok et al., "Prevalence of ANCA in mixed cryoglobulinemia and chronic hepatitis C virus infection," Clinical and Experimental Rheumatology, vol. 21, no. 6, supplement 32, pp. S89-S94, 2003.

[58] M. Cojocaru, I. M. Cojocaru, and S. A. Iacob, "Prevalence of anti-neutrophil cytoplasmic antibodies in patients with chronic hepatitis $\mathrm{C}$ infection associated mixed cryoglobulinemia," Romanian Journal of Internal Medicine, vol. 44, no. 4, pp. 427-431, 2006.

[59] A. Kessel, G. Elias, E. Pavlotzky, E. Zuckerman, I. Rosner, and E. Toubi, "Anti-C-reactive protein antibodies in chronic hepatitis $\mathrm{C}$ infection: correlation with severity and autoimmunity," Human Immunology, vol. 68, no. 10, pp. 844-848, 2007.

[60] C. Sjöwall, K. Cardell, E. A. Boström et al., "High prevalence of autoantibodies to C-reactive protein in patients with chronic hepatitis $\mathrm{C}$ infection: association with liver fibrosis and portal inflammation," Human Immunology. In press.

[61] D. Saadoun, S. Sadallah, M. Trendelenburg et al., "AntiC1q antibodies in hepatitis C virus infection," Clinical and Experimental Immunology, vol. 145, no. 2, pp. 308-312, 2006.

[62] P. Cacoub, P. Ghillani, R. Revelen et al., "Anti-endothelial cell auto-antibodies in hepatitis $\mathrm{C}$ virus mixed cryoglobulinemia," Journal of Hepatology, vol. 31, no. 4, pp. 598-603, 1999.

[63] M. Alpa, B. Ferrero, R. Cavallo et al., "Anti-neuronal antibodies in patients with HCV-related mixed cryoglobulinemia," Autoimmunity Reviews, vol. 8, no. 1, pp. 56-58, 2008.

[64] F. A. Robey, K. D. Jones, and A. D. Steinberg, "C-reactive protein mediates the solubilization of nuclear DNA by complement in vitro," Journal of Experimental Medicine, vol. 161, no. 6, pp. 1344-1356, 1985.

[65] I. Gunnarsson, J. Rönnelid, Y. H. Huang et al., "Association between ongoing anti-C1q antibody production in peripheral blood and proliferative nephritis in patients with active systemic lupus erythematosus," British Journal of Rheumatology, vol. 36, no. 1, pp. 32-37, 1997.
[66] D. W. Lienesch, K. E. Sherman, A. Metzger, and G. Q. Shen, "Anti-C1q antibodies in patients with chronic hepatitis C infection," Clinical and Experimental Rheumatology, vol. 24, no. 2, pp. 183-185, 2006.

[67] P. L. Karlsberg, W. M. Lee, D. L. Casey, C. J. Cockerell, and P. D. Cruz, "Cutaneous vasculitis and rheumatoid factor positivity as presenting signs of hepatitis $\mathrm{C}$ virus-induced mixed cryoglobulinemia," Archives of Dermatology, vol. 131, no. 10, pp. 1119-1123, 1995.

[68] F. G. De Rosa and V. Agnello, "Observations on cryoglobulin testing: I. The association of cryoglobulins containing rheumatoid factors with manifestation of cryoglobulinemic vasculitis," Journal of Rheumatology, vol. 36, no. 9, pp. 19531955, 2009.

[69] S. Beddhu, S. Bastacky, and J. P. Johnson, "The clinical and morphologic spectrum of renal cryoglobulinemia," Medicine, vol. 81, no. 5, pp. 398-409, 2002.

[70] G. B. Knight, L. Gao, L. Gragnani et al., "Detection of WA $\mathrm{B}$ cells in hepatitis $\mathrm{C}$ virus infection: a potential prognostic marker for cryoglobulinemic vasculitis and B cell malignancies," Arthritis and Rheumatism, vol. 62, no. 7, pp. 2152-2159, 2010.

[71] P. Youinou, P. L. Meroni, M. A. Khamashta, and Y. Shoenfeld, "A need for standardization of the anti-endothelial-cell antibody test," Immunology Today, vol. 16, no. 8, pp. 363-364, 1995.

[72] L. H. van den Berg, C. L. A. Lankamp, A. E. J. de Jager et al., "Anti-sulphatide antibodies in peripheral neuropathy," Journal of Neurology Neurosurgery and Psychiatry, vol. 56, no. 11, pp. 1164-1168, 1993.

[73] A. Amoroso, M. Berrino, L. Canale et al., "Are HLA class II and immunoglobulin constant region genes involved in the pathogenesis of mixed cryoglobulinemia type II after hepatitis C virus infection?" Journal of Hepatology, vol. 29, no. 1, pp. 36-44, 1998.

[74] P. Cacoub, C. Renou, G. Kerr et al., "Influence of HLA-DR phenotype on the risk of hepatitis $\mathrm{C}$ virus-associated mixed cryoglobulinemia," Arthritis and Rheumatism, vol. 44, no. 9, pp. 2118-2124, 2001.

[75] C. Jorgensen, M. C. Legouffe, P. Perney et al., "Sicca syndrome associated with hepatitis C virus infection," Arthritis and Rheumatism, vol. 39, no. 7, pp. 1166-1171, 1996.

[76] Y. Nagao, S. Hanada, S. Shishido et al., "Incidence of Sjögren's syndrome in Japanese patients with hepatitis C virus infection," Journal of Gastroenterology and Hepatology, vol. 18, no. 3, pp. 258-266, 2003.

[77] H. Verbaan, J. Carlson, S. Eriksson et al., "Extrahepatic manifestations of chronic hepatitis $\mathrm{C}$ infection and the interrelationship between primary Sjogren's syndrome and hepatitis C in Swedish patients," Journal of Internal Medicine, vol. 245, no. 2, pp. 127-132, 1999.

[78] S. Ohoka, Y. Tanaka, Y. Amako et al., "Sialadenitis in patients with chronic hepatitis $\mathrm{C}$ is not directly related to hepatitis $\mathrm{C}$ virus," Hepatology Research, vol. 27, no. 1, pp. 23-29, 2003.

[79] K. Koike, K. Moriya, K. Ishibashi et al., "Sialadenitis histologically resembling Sjögren syndrome in mice transgenic for hepatitis C virus envelope genes," Proceedings of the National Academy of Sciences of the United States of America, vol. 94, no. 1, pp. 233-236, 1997.

[80] M. Ramos-Casals, M. García-Carrasco, R. Cervera et al., "Th1/Th2 cytokine imbalance in patients with Sjögren syndrome secondary to hepatitis C virus infection," Seminars in Arthritis and Rheumatism, vol. 32, no. 1, pp. 56-63, 2002. 
[81] M. Ramos-Casals, M. García-Carrasco, M. P. B. Zeron, R. Cervera, and J. Font, "Viral etiopathogenesis of Sjögren's syndrome: role of the hepatitis C virus," Autoimmunity Reviews, vol. 1, no. 4, pp. 238-243, 2002.

[82] M. Ramos-Casals, L. la Civita, S. de Vita et al., "Characterization of B cell lymphoma in patients with Sj?gren's syndrome and hepatitis C virus infection," Arthritis and Rheumatism, vol. 57, no. 1, pp. 161-170, 2007.

[83] A. Potthoff, T. Witte, K. Rifai et al., "Prevalence of alphafodrin antibodies in patients with chronic hepatitis $\mathrm{C}$ infection and Sjgren syndrome," Scandinavian Journal of Gastroenterology, vol. 44, no. 8, pp. 994-1003, 2009.

[84] M. Ramos-Casals, M. Garć́a-Carrasco, R. Cervera et al., "Hepatitis $\mathrm{C}$ virus infection mimicking primary Sjögren syndrome: a clinical and immunologic description of 35 cases," Medicine, vol. 80, no. 1, pp. 1-8, 2001.

[85] P. Brito-Zeron, S. Retamozo, M. Gandia et al., "Monoclonal gammopathy related to Sjögren syndrome: a key marker of disease prognosis and outcomes," Journal of Autoimmunity. In press.

[86] S. DeVita, L. Quatuccio, S. Salvin et al., "Cryoglobulinaemia related to Sjögren's syndrome or HCV infection: differences based on the pattern of bone marrow involvement, lymphoma evolution and laboratory tests after parotidectomy," Rheumatology, vol. 51, no. 4, pp. 627-633, 2012.

[87] C. A. Scott, C. Avellini, L. Desinan et al., "Chronic lymphocytic sialoadenitis in HCV-related chronic liver disease: comparison with Sjogren's syndrome," Histopathology, vol. 30, no. 1, pp. 41-48, 1997.

[88] C. M. Smyth, S. M. McKiernan, R. Hagan et al., "Chronic hepatitis $\mathrm{C}$ infection and sicca syndrome: a clear association with HLA DQB1*02," European Journal of Gastroenterology and Hepatology, vol. 19, no. 6, pp. 493-498, 2007.

[89] R. W. Wilson, T. T. Provost, and W. B. Bias, “Sjogren's syndrome. Influence of multiple HLA-D region alloantigens on clinical and serologic expression," Arthritis and Rheumatism, vol. 27, no. 11, pp. 1245-1253, 1984.

[90] M. Deutsch, S. Dourakis, E. K. Manesis et al., “Thyroid abnormalities in chronic viral hepatitis and their relationship to interferon alfa therapy," Hepatology, vol. 26, no. 1, pp. 206210, 1997.

[91] N. Ganne-Carrie, A. Medini, E. Coderc et al., "Latent autoimmune thyroiditis in untreated patients with HCV chronic hepatitis: a case-control study," Journal of Autoimmunity, vol. 14, no. 2, pp. 189-193, 2000.

[92] A. Antonelli, C. Ferri, A. Pampana et al., "Thyroid disorders in chronic hepatitis C," American Journal of Medicine, vol. 117, no. 1, pp. 10-13, 2004.

[93] K. M. Kee, C. M. Lee, J. H. Wang et al., “Thyroid dysfunction in patients with chronic hepatitis $\mathrm{C}$ receiving a combined therapy of interferon and ribavirin: incidence, associated factors and prognosis," Journal of Gastroenterology and Hepatology, vol. 21, no. 1, part 2, pp. 319-326, 2006.

[94] J. C. Mandac, S. Chaudhry, K. E. Sherman, and Y. Tomer, "The clinical and physiological spectrum of interferon-alpha induced thyroiditis: toward a new classification," Hepatology, vol. 43, no. 4, pp. 661-672, 2006.

[95] M. F. Prummel and P. Laurberg, "Interferon- $\alpha$ and autoimmune thyroid disease," Thyroid, vol. 13, no. 6, pp. 547-551, 2003.

[96] M. Nishioka, S. A. Morshed, K. Kono et al., "Frequency and significance of antibodies to P450IID6 protein in Japanese patients with chronic hepatitis C," Journal of Hepatology, vol. 26, no. 5, pp. 992-1000, 1997.
[97] L. Muratori, D. P. Bogdanos, P. Muratori et al., "Susceptibility to thyroid disorders in hepatitis C," Clinical Gastroenterology and Hepatology, vol. 3, no. 6, pp. 595-603, 2005.

[98] S. J. Hadziyannis, "Skin diseases associated with hepatitis C virus infection," Journal of the European Academy of Dermatology and Venereology, vol. 10, no. 1, pp. 12-21, 1998.

[99] C. Jubert, J. M. Pawlotsky, F. Puget et al., "Lichen-planus and hepatitis C virus-related chronic active hepatitis," Archives of Dermatology, vol. 130, no. 1, pp. 73-76, 1994.

[100] Y. Nagao, M. Sata, M. Kage, T. Kameyama, and T. Ueno, "Histopathological and immunohistochemical study of oral lichen planus-associated HCV infection," European Journal of Internal Medicine, vol. 11, no. 5, pp. 277-282, 2000.

[101] G. R. Hughes, N. N. Harris, and A. E. Gharavi, "The anticardiolipin syndrome," The Journal of Rheumatology, vol. 13, no. 3, pp. 486-489, 1986.

[102] Y. Nagao, K. Tsubone, R. Kimura et al., "High prevalence of anticardiolipin antibodies in patients with $\mathrm{HCV}$-associated oral lichen planus," International Journal of Molecular Medicine, vol. 9, no. 3, pp. 293-297, 2002.

[103] T. Himoto, H. Yoneyama, K. Kurokohchi et al., "Clinical relevance of antibodies to cardiolipin antibodies in chronic hepatitis C," Journal of Clinical Laboratory Analysis. In press.

[104] J. Y. F. Chang, C. P. Chiang, C. K. Hsiao, and A. Sun, "Significantly higher frequencies of presence of serum autoantibodies in Chinese patients with oral lichen planus," Journal of Oral Pathology and Medicine, vol. 38, no. 1, pp. 48-54, 2009.

[105] G. Lodi, I. Olsen, A. Piattelli, E. D’Amico, L. Artese, and S. R. Porter, "Antibodies to epithelial components in oral lichen planus (OLP) associated with hepatitis C virus (HCV) infection," Journal of Oral Pathology and Medicine, vol. 26, no. 1, pp. 36-39, 1997.

[106] M. Carrozzo, S. Gandolfo, G. Lodi et al., "Oral lichen planus in patients infected or noninfected with hepatitis $\mathrm{C}$ virus: the role of autoimmunity," Journal of Oral Pathology and Medicine, vol. 28, no. 1, pp. 16-19, 1999.

[107] T. Himoto, S. Nakai, F. Kinekawa et al., "Clinical characteristics of patients with hepatitis $\mathrm{C}$ virus-related chronic liver disease seropositive for anticentromere antibody," Digestive Diseases and Sciences, vol. 54, no. 2, pp. 360-368, 2009.

[108] Y. Moroi, C. Peebles, and M. J. Fritzler, "Autoantibody to centromere (kinetochore) in scleroderma sera," Proceedings of the National Academy of Sciences of the United States of America, vol. 77, no. 3, pp. 1627-1631, 1980.

[109] J. Tojo, H. Ohira, T. Suzuki et al., "Clinicolaboratory characteristics of patients with primary biliary cirrhosis associated with CREST symptoms," Hepatology Research, vol. 22, no. 3, pp. 187-195, 2002.

[110] Y. Muro, N. Azuma, H. Onouchi et al., "Autoepitopes on autoantigen centromere protein-A (CENP-A) are restricted to the N-terminal region, which has no homology with histone H3," Clinical and Experimental Immunology, vol. 120, no. 1, pp. 218-223, 2000.

[111] W. C. Earnshaw and N. Rothfield, "Identification of a family of human centromere proteins using autoimmune sera from patients with scleroderma," Chromosoma, vol. 91, no. 3-4, pp. 313-321, 1985.

[112] Y. Tomer, "Hepatitis C and interferon induced thyroiditis," Journal of Autoimmunity, vol. 34, no. 3, pp. J322-J326, 2010.

[113] W. B. Chan, C. C. Chow, and C. S. Cockram, "Interferon alpha treatment and endocrine disease," Journal of the Royal Society of Medicine, vol. 96, no. 10, pp. 481-485, 2003. 
[114] M. J. Rowley, I. R. Mackay, Q. Y. Chen, W. J. Knowles, and P. Z. Zimmet, "Antibodies to glutamic acid decarboxylase discriminate major types of diabetes mellitus," Diabetes, vol. 41, no. 4, pp. 548-551, 1992.

[115] C. Betterle, P. Fabris, R. Zanchetta et al., "Autoimmunity against pancreatic islets and other tissues before and after interferon- $\alpha$ therapy in patients with hepatitis $C$ virus chronic infection," Diabetes Care, vol. 23, no. 8, pp. 1177-1181, 2000.

[116] S. Piquer, C. Hernández, J. Enriquez et al., "Islet cell and thyroid antibody prevalence in patients with hepatitis $\mathrm{C}$ virus infection: effect of treatment with interferon," Journal of Laboratory and Clinical Medicine, vol. 137, no. 1, pp. 38-42, 2001.

[117] P. Fabris, C. Betterle, N. A. Greggio et al., "Insulin-dependent diabetes mellitus during alpha-interferon therapy for chronic viral hepatitis," Journal of Hepatology, vol. 28, no. 3, pp. 514$517,1998$.

[118] B. Wesche, E. Jaeckel, C. Trautwein et al., "Induction of autoantibodies to the adrenal cortex and pancreatic islet cells by interferon alpha therapy for chronic hepatitis C," Gut, vol. 48, no. 3, pp. 378-383, 2001.

[119] N. K. Gatselis, S. P. Georgiadou, G. K. Koukoulis et al., "Clinical significance of organ- and non-organ-specific autoantibodies on the response to anti-viral treatment of patients with chronic hepatitis C," Alimentary Pharmacology and Therapeutics, vol. 24, no. 11-12, pp. 1563-1573, 2006.

[120] G. Covini, W. C. Carcamo, E. Bredi et al., "Cytoplasmic rods and rings autoantibodies developed during pegylated interferon and ribavirin therapy in patients with chronic hepatitis C," Antiviral Therapy. In press.

[121] S. Kakizaki, H. Takagi, M. Murakami, H. Takayama, and M. Mori, "HLA antigens in patients with interferon- $\alpha$-induced autoimmune thyroid disorders in chronic hepatitis C," Journal of Hepatology, vol. 30, no. 5, pp. 794-800, 1999.

[122] A. Martocchia, G. Labbadia, V. Paoletti et al., "Hashimoto's disease during interferon-alpha therapy in a patient with pretreatment negative anti-thyroid autoantibodies and with the specific genetic susceptibility to the thyroid disease," Neuroendocrinology Letters, vol. 22, no. 1, pp. 49-52, 2001.

[123] C. Ferri, A. Antonelli, M. T. Mascia et al., "HCV-related autoimmune and neoplastic disorders: the HCV syndrome," Digestive and Liver Disease, vol. 39, supplement 1, pp. S13S21, 2007.

[124] F. Invernizzi, M. Galli, G. Serino et al., "Secondary and essential cryoglobulinemias. Frequency, nosological classification, and long-term follow-up," Acta Haematologica, vol. 70, no. 2, pp. 73-82, 1983.

[125] A. L. Zignego, C. Giannini, and C. Ferri, "Hepatitis C virusrelated lymphoproliferative disorders: an overview," World Journal of Gastroenterology, vol. 13, no. 17, pp. 2467-2478, 2007.

[126] S. J. Korsmeyer, "Bcl-2: a repressor of lymphocyte death," Immunology Today, vol. 13, no. 8, pp. 285-287, 1992.

[127] A. L. Zignego, F. Giannelli, M. E. Marrocchi et al., "Frequency of bcl-2 rearrangement in patients with mixed cryoglobulinemia and HCV-positive liver diseases," Clinical and Experimental Rheumatology, vol. 15, no. 6, pp. 711-712, 1997.

[128] A. L. Zignego, C. Ferri, F. Giannelli et al., "Prevalence of bcl2 rearrangement in patients with hepatitis C virus-related mixed cryoglobulinemia with or without B-cell lymphomas," Annals of Internal Medicine, vol. 137, no. 7, pp. 571-580, 2002 .
[129] M. Ellis, M. Rathaus, A. Amiel, Y. Manor, A. Klein, and M. Lishner, "Monoclonal lymphocyte proliferation and bcl-2 rearrangement in essential mixed cryoglobulinaemia," European Journal of Clinical Investigation, vol. 25, no. 11, pp. 833837, 1995.

[130] K. Machida, K. T. N. Cheng, V. M. H. Sung et al., "Hepatitis $\mathrm{C}$ virus induces a mutator phenotype: enhanced mutations of immunoglobulin and protooncogenes," Proceedings of the National Academy of Sciences of the United States of America, vol. 101, no. 12, pp. 4262-4267, 2004.

[131] P. Andreone, A. L. Zignego, C. Cursaro et al., "Prevalence of monoclonal gammopathies in patients with hepatitis $\mathrm{C}$ virus infection," Annals of Internal Medicine, vol. 129, no. 4, pp. 294-298, 1998.

[132] R. Idilman, A. Colantoni, N. De Maria, S. Alkan, S. Nand, and D. H. Van Thiel, "Lymphoproliferative disorders in chronic hepatitis C," Journal of Viral Hepatitis, vol. 11, no. 4, pp. 302309, 2004.

[133] R. Bartl, B. Frisch, and A. Fateh-Moghadam, "Histologic classification and staging of multiple myeloma. A retrospective and prospective study of 674 cases," American Journal of Clinical Pathology, vol. 87, no. 3, pp. 342-355, 1987.

[134] J. Raedle, W. K. Roth, G. Oremek, W. F. Caspary, and S. Zeuzem, " $\alpha$-Fetoprotein and p53 autoantibodies in patients with chronic hepatitis C," Digestive Diseases and Sciences, vol. 40, no. 12, pp. 2587-2594, 1995.

[135] M. E. Perry and A. J. Levine, "Tumor-suppressor p53 and the cell cycle," Current Opinion in Genetics and Development, vol. 3, no. 1, pp. 50-54, 1993.

[136] A. Yagihashi, K. Asanuma, D. Kobayashi et al., "Autoantibodies to survivin in patients with chronic hepatitis and hepatocellular carcinoma," Autoimmunity, vol. 38, no. 6, pp. 445448, 2005.

[137] G. Ambrosini, C. Adida, and D. C. Altieri, "A novel anti-apoptosis gene, survivin, expressed in cancer and lymphoma," Nature Medicine, vol. 3, no. 8, pp. 917-921, 1997.

[138] T. Himoto, S. Kuriyama, J. Y. Zhang, E. K. Chan, M. Nishioka, and E. M. Tan, "Significance of autoantibodies against insulin-like growth factor II mRNA-binding proteins in patients with hepatocellular carcinoma," International Journal of Oncology, vol. 26, no. 2, pp. 314-317, 2005.

[139] T. Himoto, S. Kuriyama, J. Y. Zhang et al., "Analyses of autoantibodies against tumor-associated antigens in patients with hepatocellular carcinoma," International Journal of Oncology, vol. 27, no. 4, pp. 1079-1085, 2005.

[140] H. S. Hong, S. A. Morshed, S. Tanaka, T. Fujiwara, Y. Ikehara, and M. Nishioka, "Anti-Golgi antibody in rheumatoid arthritis patients recognizes a novel antigen of $79 \mathrm{kDa}$ (doublet) by Western blot," Scandinavian Journal of Immunology, vol. 36, no. 6, pp. 785-792, 1992.

[141] L. Mozo, A. Simó, A. Suárez, L. Rodrigo, and C. Gutiérrez, "Autoantibodies to Golgi proteins in hepatocellular carcinoma: case report and literature review," European Journal of Gastroenterology and Hepatology, vol. 14, no. 7, pp. 771-774, 2002.

[142] E. Briasoulis, K. Kamposioras, V. Tzovaras et al., "CENP-B specific anti-centromere autoantibodies heralding small-cell lung cancer. A case study and review of the literature," Lung Cancer, vol. 60, no. 2, pp. 302-306, 2008.

[143] M. Ramos-Casals, M. García-Carrasco, F. López-Medrano et al., "Severe autoimmune cytopenias in treatment-naive hepatitis C virus infection clinical description of 35 cases," Medicine, vol. 82, no. 2, pp. 87-96, 2003. 
[144] J. F. Dufour, P. Pradat, M. Ruivard et al., "Severe autoimmune cytopenias in treatment-naive hepatitis $\mathrm{C}$ virus infection: clinical description of 16 cases," European Journal of Gastroenterology and Hepatology, vol. 21, no. 3, pp. 245-253, 2009.

[145] S. Panzer, E. Seel, M. Brunner et al., "Platelet autoantibodies are common in hepatitis $\mathrm{C}$ infection, irrespective of the presence of thrombocytopenia," European Journal of Haematology, vol. 77, no. 6, pp. 513-517, 2006.

[146] S. Aref, T. Sleem, N. E. Menshawy et al., "Antiplatelet antibodies contribute to thrombocytopenia associated with chronic hepatitis C virus infection," Hematology, vol. 14, no. 5, pp. 277-281, 2009.

[147] N. Ishizaka, Y. Ishizaka, E. Takahashi et al., "Association between hepatitis $\mathrm{C}$ virus seropositivity, carotid-artery plaque, and intima-media thickening," The Lancet, vol. 359, no. 9301, pp. 133-135, 2002.

[148] J. T. Wu and L. L. Wu, "Autoantibodies against oxidized LDL: a potential marker for atherosclerosis," Clinics in Laboratory Medicine, vol. 17, no. 3, pp. 595-604, 1997.

[149] T. Himoto, H. Yoneyama, A. Deguchi et al., "Relationship between the production of autoantibodies to oxidized lowdensity lipoprptein and hepatic steatosis in patients with chronic hepatitis C," Experimental and Therapeutic Medicine, vol. 1, no. 4, pp. 663-668, 2010. 


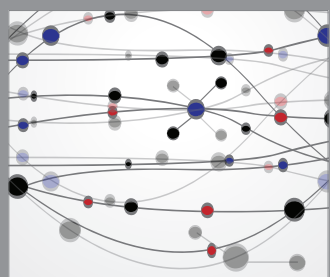

The Scientific World Journal
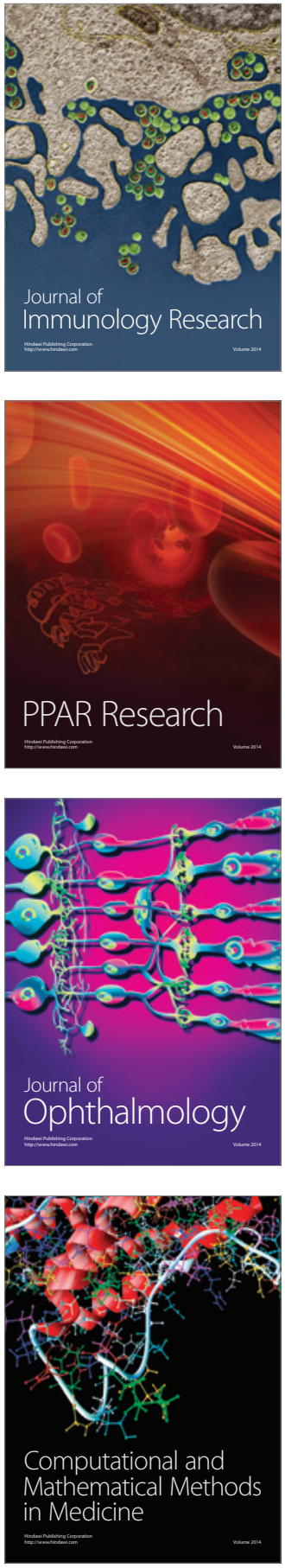

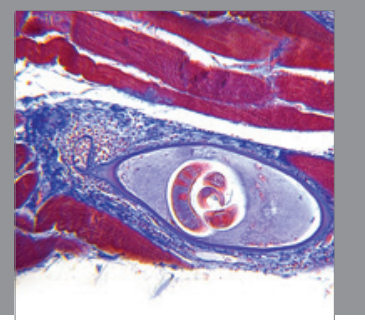

Gastroenterology

Research and Practice
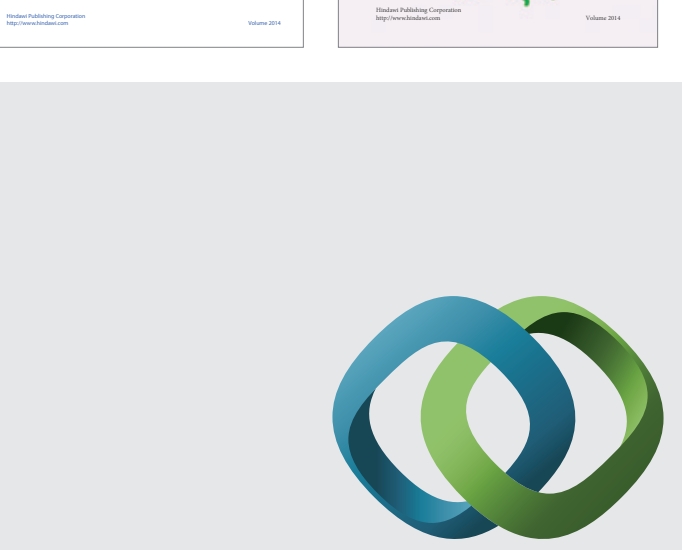

\section{Hindawi}

Submit your manuscripts at

http://www.hindawi.com
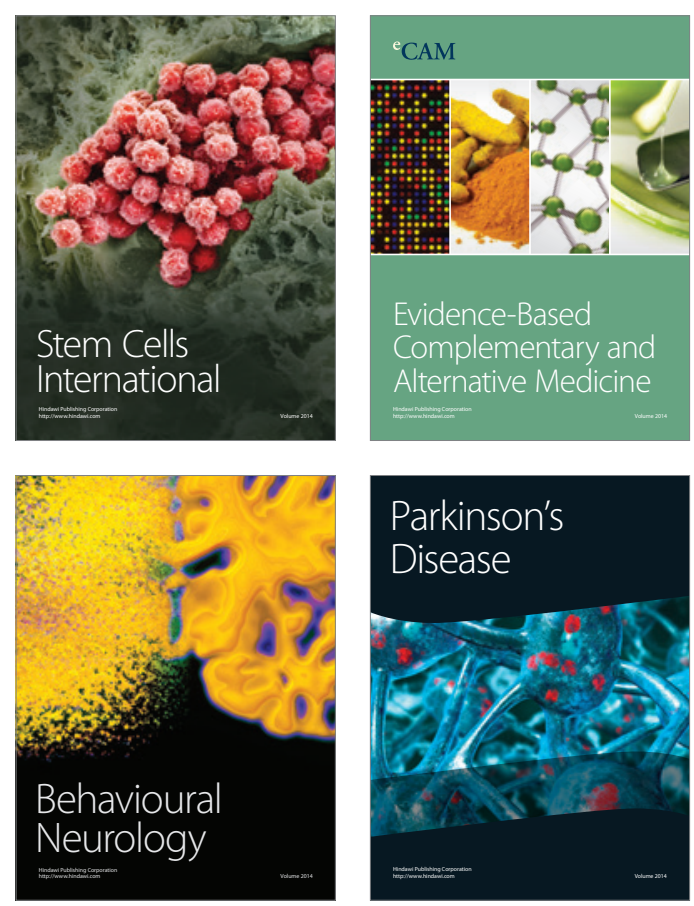

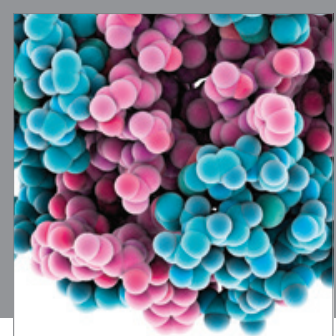

Journal of
Diabetes Research

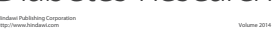

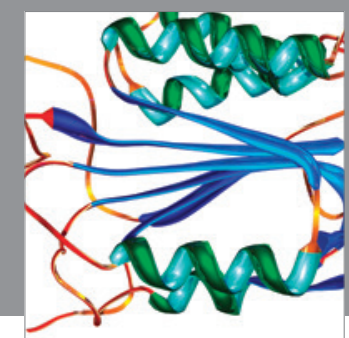

Disease Markers
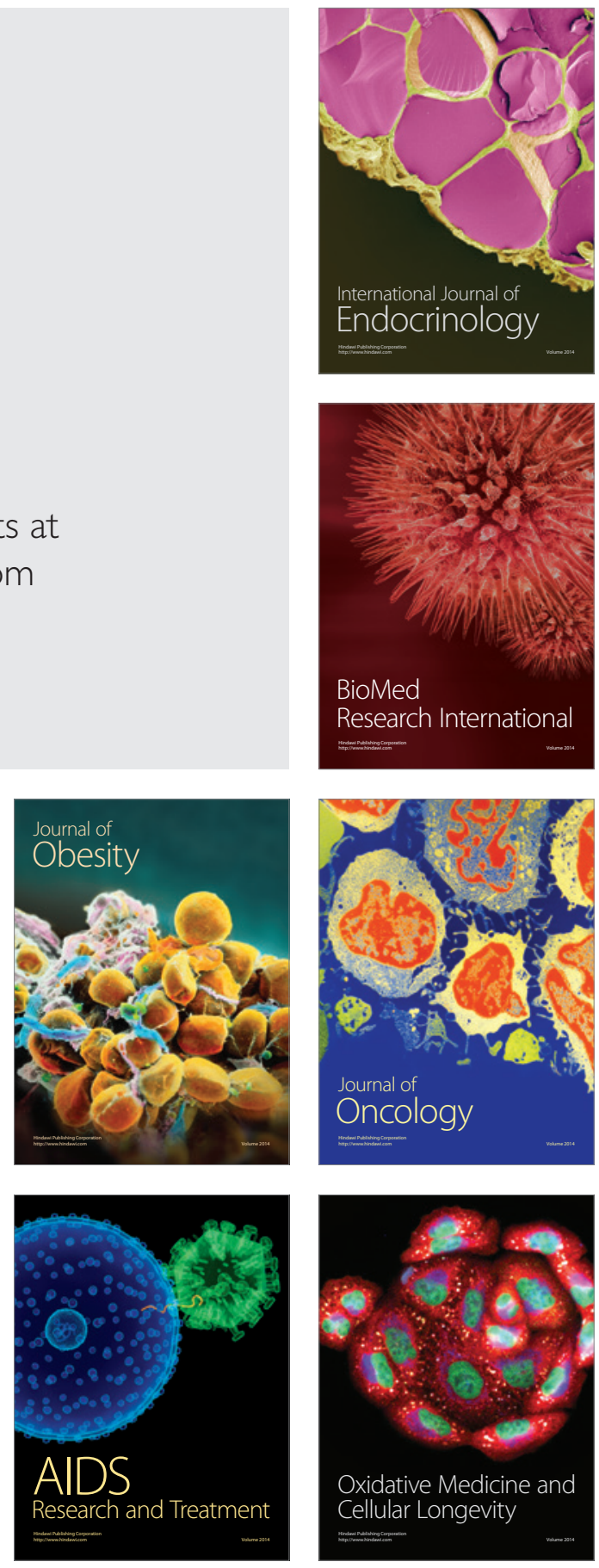